\title{
Immunogenicity of highly purified bovine insulin: a comparison with conventional bovine and highly purified human insulins
}

\author{
R. M. Wilson, C.A. Douglas, R. B. Tattersall and W.G. Reeves \\ Departments of Immunology and Medicine, University Hospital, Queen's Medical Centre, Nottingham, UK
}

\begin{abstract}
Summary. Twenty-six Type 1 diabetic patients previously treated for 10-20 months with twice daily conventional bovine isophane insulin (containing at least $1000 \mathrm{ppm}$ proinsulin) were changed to highly purified $(<1 \mathrm{ppm}$ proinsulin) bovine isophane for 6 months (Switch group). Insulin antibody levels fell significantly from a geometric mean of 14.9 to $9.1 \mu \mathrm{g} / 1$. Thirty-two patients with newly diagnosed Type 1 diabetes were treated with the same highly purified bovine isophane insulin twice daily for 6 months (Starter group). Their insulin antibody levels rose from a geometric mean of 1.9 to $8.2 \mu \mathrm{g} / 1$ in contrast to values of 1.4 rising to $16.3 \mu \mathrm{g} / 1$ in an age and sex matched historical control group treated from diagnosis only with twice daily conventional bovine isophane insulin. Lipoatrophy at injection sites developed in three (9\%) in the Starter group treated with highly purified bovine isophane
\end{abstract}

compared to $7(22 \%)$ of those on conventional bovine isophane. Insulin dose and diabetic control did not differ between the groups. Starter and Switch groups were subsequently treated with semi-synthetic human isophane insulin for 6 months during which insulin antibody levels fell significantly from a geometric mean of 8.5 to $4.4 \mu \mathrm{g} / 1(p<0.001)$. We conclude that bovine insulin purified to less than $1 \mathrm{ppm}$ proinsulin is significantly less immunogenic than its conventional proinsulin contaminated counterpart but even at this level of purity is still more immunogenic than human insulin of equivalent purity.

Key words: Immunogenicity, Bovine insulin, Lipoatrophy, Insulin antibodies, Human insulin
Previous studies [1-3] have shown that bovine insulin purified by sequential recrystallisation to $>1000 \mathrm{ppm}$ proinsulin (conventional bovine insulin) is much more immunogenic that its highly purified $(<1 \mathrm{ppm}$ proinsulin) porcine counterpart. Not only are levels of insulin antibody higher but antibodies to C-peptide and other islet proteins are often present after using the conventional preparation [3-6]. We previously studied patients on conventional bovine soluble and isophane insulins who were transferred to equivalent bovine preparations purified to a proinsulin content of $20-40 \mathrm{ppm}$ [7]. This significantly reduced antibodies reactive with $\mathrm{C}$ peptide but did not change insulin antibody levels. It left open the question of whether bovine insulin is inherently more immunogenic than pork or human because the "purified" bovine still contained significantly more proinsulin than the porcine with which it was compared. In the present study we have examined the immunogenicity of highly purified bovine isophane insulin (containing $<1 \mathrm{ppm}$ proinsulin) and compared it with a conventional bovine isophane and semi-synthetic human isophane insulin.

\section{Patients}

\section{Switch group}

Twenty-six patients with Type 1 diabetes were treated from diagnosis 10-20 months earlier with twice daily conventional bovine (CB) isophane insulin only. They and the other patients reported in this paper had all been started on insulin as outpatients and had never received soluble insulin. These 26 were then switched to highly purified bovine isophane insulin (HPB) for 6 months followed by semi-synthetic human isophane (SSH) for a further 6 months. Half the group were men with a mean age of 39 years (range 19-72) compared to 38 years (range 15-67) for the women.

\section{Starter group}

Thirty-two newly diagnosed insulin-requiring patients, part of a series of 100 reported els-where [8], received highly purified bovine isophane insulin (HPB) twice daily for the first 6 months after diagnosis followed by semi-synthetic human isophane (SSH) twice daily for a further 6 months. There were 22 men of mean age 28 years (range $11-67$ ) and 10 women (mean age 26 years: range 19-70). All had acute onset Type 1 diabetes except a 70 -year-old woman who needed insulin treatment because of hyperglycaemia and weight loss uncontrolled by maximum doses of oral hypoglycaemic agents. 


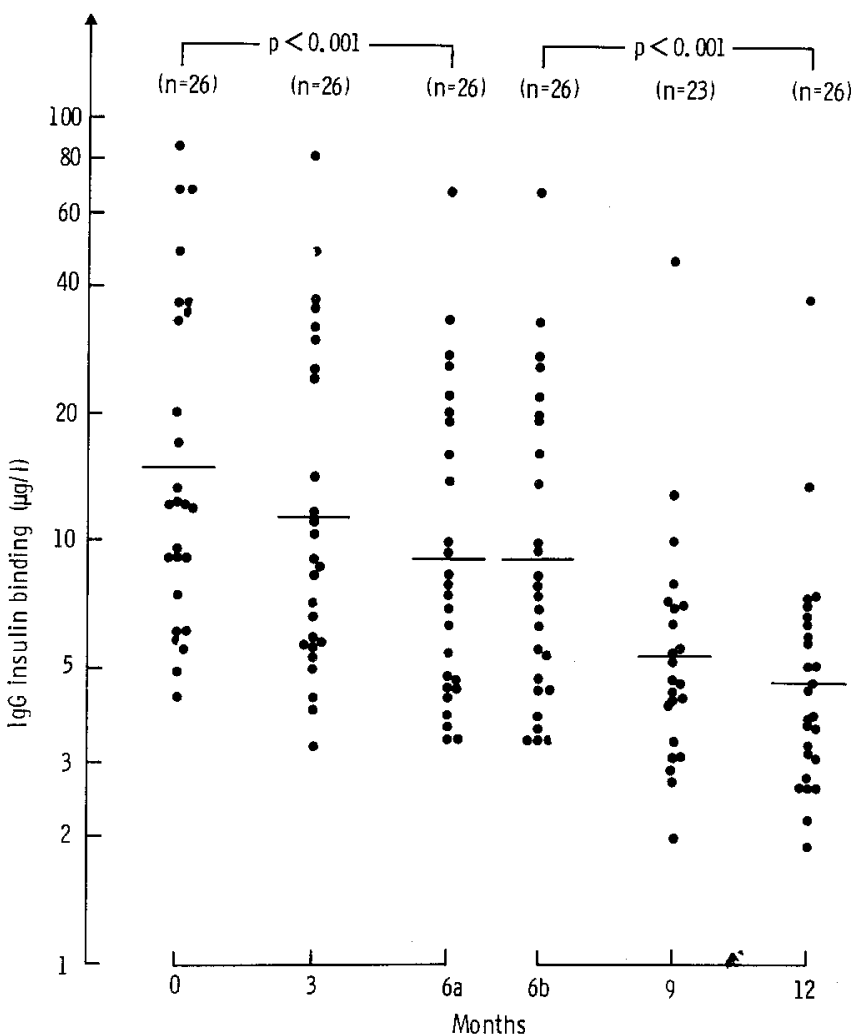

Fig. 1. IgG insulin binding (bovine ligand) in the Switch group. The 26 patients had been treated exclusively with bovine isophane prior to entry at month 0 . They then received highly purified bovine insulin for 6 months ( 0 to $6 \mathrm{a}$ ) followed by highly purified human insulin for a further 6 months ( $6 \mathrm{~b}$ to 12 )

To compare the effects of HPB isophane insulin with a conventional bovine preparation, we chose patients from another study performed by us [9] in which treatment was exclusively with twice daily CB from diagnosis. Matching was done blind from a pool of 120 patients who were matched for sex, diabetes type and age to within 5 years.

All patients with Type 1 diabetes fulfilled the following criteria at diagnosis: ketonuria of $3.9 \mathrm{mmol} / 1$ or greater ("moderate" or "large" with ketostix: Ames Company Ltd., Elkhardt, Indiana, USA) and/or two of the following: (a) acute onset of symptoms (present less than 1 month); (b) body mass index (BMI) of less than $24 \mathrm{~kg} / \mathrm{m}^{2}$ or marked weight loss; (c) severe symptoms; (d) a first degree relative on insulin. These indices have been examined in relation to presence of islet cell antibodies and possession of HLA DR3 and/or DR4 and have been shown to be valid diagnostic criteria for Type 1 diabetes [8]. No patient in any of the three groups had diabetic complications, none was on any drug treatment and none had any serious incidental disease.

\section{Materials and methods}

The conventional bovine isophane insulins used in this study were obtained from Evans Medical Ltd. (Beaconsfield, UK) and Weddel Pharmaceuticals Ltd. (London, UK) and contained at least $1000 \mathrm{ppm}$ proinsulin. Highly purified "monocomponent" bovine isophane and semi-synthetic human isophane (Protaphane Human) were supplied by Novo Industries, Copenhagen and contained $<1 \mathrm{ppm}$ proinsulin. All patients were seen by a single doctor (RMW) and their insulin preparations carefully checked. None was admitted to hospital during the study and we are as certain as it is possible to be that they did not receive any other insulin preparation. IgG insulin antibody reactive with ${ }^{125}$ I-labelled bovine or human insulin was measured as described

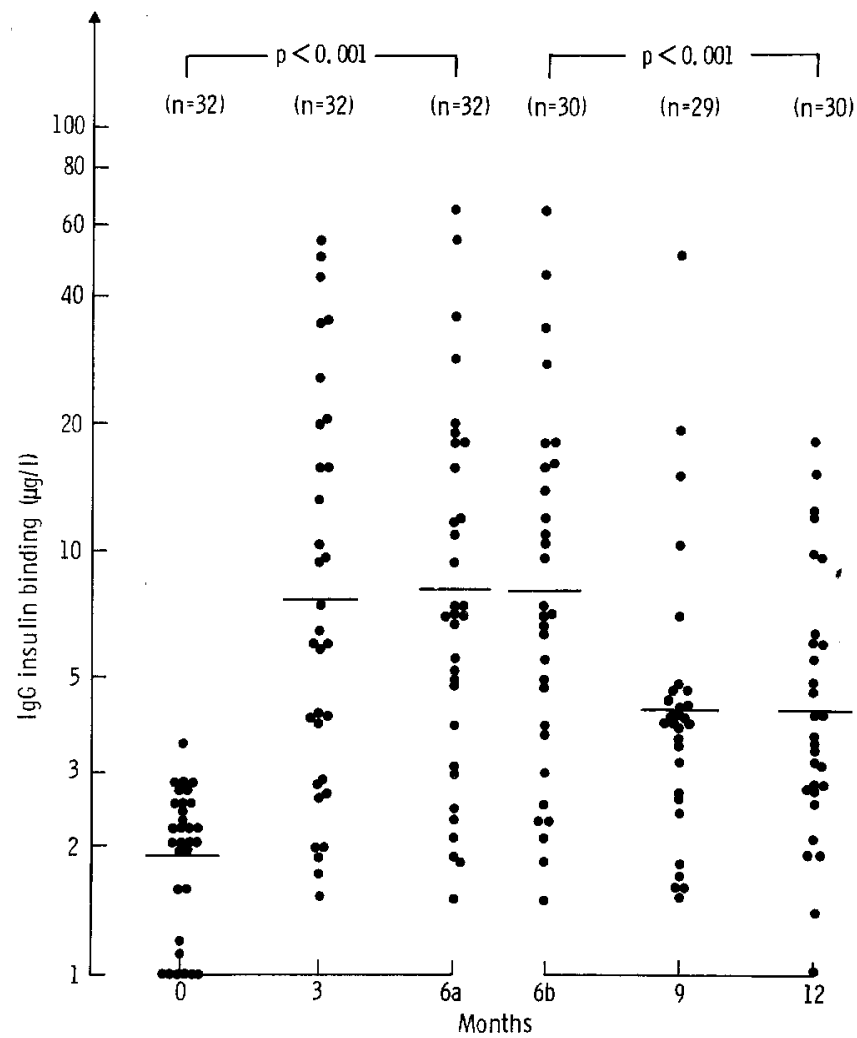

Fig.2. IgG insulin binding (bovine ligand) in the Starter group. The 32 patients had newly diagnosed diabetes and were treated with highly purified bovine insulin for 6 months ( 0 to 6 a) followed by highly purified human insulin for a further 6 months ( $6 \mathrm{~b}$ to 12$)$

previously [6]. Insulin was removed from sera before assay and results expressed in $\mu \mathrm{g} / 1$ without subtraction of a value for normal serum binding [6]. Haemoglobin $\mathrm{Al}\left(\mathrm{HbA}_{1}\right)$ was measured by electroendosmosis (Corning Medical and Scientific, Medfield, Mass, USA) [10]. The normal range (mean $\pm 2 \mathrm{SD}$ in non-diabetic patients) in our laboratory is $5-10 \%[11]$.

\section{Statistical methods}

$\log _{e}$ transformation of the insulin antibody results was used to normalise the distribution. Statistical analysis employed standard Student's t-test and its modification for paired differences.

\section{Results}

\section{Insulin antibody levels}

Figure 1 shows insulin antibody levels for the Switch group who, up to the point of entry in the present study (month 0 ), had been treated exclusively with twice daily CB isophane insulin for between 10 and 20 months. After changing to HPB isophane insulin (months 0-6a) insulin antibody levels fell from a geometric mean of 14.9 to $9.1 \mu \mathrm{g} / 1(p<0.001)$. They were then treated with SSH isophane insulin for a further 6 months (months $6 \mathrm{~b}-12$ ). Two were on HPB for longer than 6 months before transfer to SSH and it is for this reason that data for the 
Table 1. IgG antibody binding to labelled bovine insulin before and six months after treatment with highly purified (HPB) or conventional bovine (CB) isophane insulins

\begin{tabular}{llllll}
\hline & \multicolumn{2}{l}{ Before insulin treatment } & \multicolumn{2}{l}{ Six months later } \\
\hline & $\log _{\mathrm{e}}$ mean & $\begin{array}{l}\text { Geometric } \\
\text { mean }\end{array}$ & $\log _{\mathrm{e}}$ mean & $\begin{array}{l}\text { Geometric } \\
\text { mean }\end{array}$ \\
$\begin{array}{l}\text { Starter } \\
\begin{array}{l}\text { group (HPB } \\
\text { insulin) }\end{array}\end{array}$ & $0.63 \pm 0.07$ & $1.9 \mu \mathrm{g} / 1$ & 2.1 & \pm 0.17 & $8.2^{\mathrm{a}} \mu \mathrm{g} / 1$ \\
$\begin{array}{l}\text { Control } \\
\text { group (CB } \\
\text { insulin) }\end{array}$ & $0.33 \pm 0.12$ & $1.4 \mu \mathrm{g} / 1$ & $2.79 \pm 0.18$ & $16.3^{\mathrm{a}} \mu \mathrm{g} / 1$ \\
\hline
\end{tabular}

a These values are significantly different $(p<0.001)$

Table 2. IgG antibody binding to labelled bovine and human insulins in 56 patients transferred from highly purified bovine to highly purified human isophane insulin

\begin{tabular}{|c|c|c|c|c|}
\hline & On transfer & & Six months later & $p$ value \\
\hline & $\log _{e}$ mean & $\begin{array}{l}\text { Geometric } \\
\text { mean }\end{array}$ & $\begin{array}{c}\log _{e} \text { mean Geometric } \\
\text { mean }\end{array}$ & \\
\hline $\begin{array}{l}\text { Bovine } \\
\text { binding }\end{array}$ & $2.14 \pm 0.89$ & $8.5 \mu \mathrm{g} / 1$ & $1.48 \pm 0.664 .4 \mu \mathrm{g} / 1$ & $<0.001$ \\
\hline $\begin{array}{l}\text { Human } \\
\text { binding }\end{array}$ & $1.87 \pm 0.79$ & $6.5 \mu \mathrm{g} / 1$ & $1.16 \pm 0.573 .2 \mu \mathrm{g} / \mathrm{l}$ & $<0.001$ \\
\hline
\end{tabular}

end of the first 6 months treatment and the beginning of the second 6 month period have been separated into two columns (6a and $6 \mathrm{~b}$ ) although there is no significant difference between the means of the two. A further significant fall in insulin antibody levels occurred during treatment with $\mathrm{SSH}$ (months $6 \mathrm{~b}-12$ ) from 9.1 to $4.6 \mu \mathrm{g} / 1(p<0.001)$.

The Starter group (Fig. 2) were treated with HPB isophane insulin from diagnosis (months 0-6a) and then transferred to $\mathrm{SSH}$ isophane for a second period of six months (months 6b-12). For the first 6 months after diagnosis, while on HPB, insulin antibody levels rose to a geometric mean of $8.1 \mu \mathrm{g} / 1$ compared to $16.3 \mu \mathrm{g} / 1$ in the matched control group who received conventional bovine isophane for the first 6 months of treatment $(p<$ 0.001 ; Table 1). Antibody levels fell significantly during the second treatment period in the Starter group (Fig. 2) from 8.0 to $4.2 \mu \mathrm{g} / 1(p<0.001)$. Nine patients were treated with HPB for more than 6 months so that nine points differ between months $6 \mathrm{a}$ and $6 \mathrm{~b}$. However, there is no significant difference between geometric means for these two groups.

Another indication of the greater immunogenicity of $\mathrm{CB}$ insulin is that after at least 6 months on CB only two (7\%) patients in the Switch group had insulin antibody levels within the range of normal serum binding $(<5 \mu \mathrm{g} / \mathrm{l})$ whereas $10(30 \%)$ of the Starter group were still within this range of binding after 6 months on HPB. Lipoatrophy at injection sites developed in seven (22\%) of those treated with $\mathrm{CB}$ isophane compared to only three $(9 \%)$ in the Starter group treated with HPB.
After 6 months' treatment with HPB isophane insulin, antibody levels did not differ significantly between the Starter and the Switch groups (8.2 vs $9.1 \mu \mathrm{g} / 1$ respectively) indicating that previous treatment with $\mathrm{CB}$ isophane insulin does not influence final levels of antibody 6 months after transfer to HPB insulin.

For the purposes of illustration Table 2 shows pooled data for the SSH insulin treatment period for both the Switch and Starter groups. IgG antibody binding to both labelled bovine and human ligands fell significantly during this period $(p<0.001)$.

\section{Insulin dose and diabetic control}

This study was not specifically designed to examine the effects of insulin antibodies on insulin dose and diabetic control but doses and $\mathrm{HbAl}$ levels were similar after six months treatment with $\mathrm{CB}$ or HPB insulin. Patients treated with $\mathrm{CB}$ isophane insulin twice daily took $0.42 \pm 0.19$ (SD) $\mathrm{U} / \mathrm{kg} /$ day compared with $0.39 \pm$ $0.16 \mathrm{U} / \mathrm{kg}$ per day for those treated with HPB $(p>0.1)$. Mean $\mathrm{HbAl}$ in patients receiving $\mathrm{CB}$ was $11.4 \pm 2.2 \%$ compared with $10.4 \pm 3.5 \%$ for those treated with HPB $(p>0.1)$. No elective reduction in dose was made on changing to human insulin. Mean $\mathrm{HbAl}$ concentration rose slightly but not significantly $(p>0.1)$ in both groups during treatment with human insulin, from $10.9 \pm 3.5$ to $11.5 \pm 2.9 \%$ in the Starter group and from $10.0 \pm 2.9$ to $10.6 \pm 3.1 \%$ in the Switch group.

\section{Discussion}

Previous studies have shown that changing from conventional bovine to highly purified porcine insulin (i.e. a change in both species and purity) reduces levels of insulin antibody and antibodies reactive with other pancreatic peptides and hormones [2, 3, 7, 12]. However, we [7] found that a reduction in proinsulin contamination of bovine insulin to $20-40 \mathrm{ppm}$ did not lower antibody levels in patients previously "immunised" with a conventional bovine preparation. The availability of bovine insulin purified to $<1 \mathrm{ppm}$ proinsulin has allowed us to examine the intrinsic immunogenicity of bovine insulin. The present study shows that purifying bovine insulin to $<1 \mathrm{ppm}$ proinsulin does reduce antibody levels in patients previously treated with $\mathrm{CB}$ insulin. Only two patients $(7 \%)$ in the Switch group had antibody levels within the range of normal serum binding whereas ten $(30 \%)$ in the Starter group were below this level after 6 months treatment with HPB. This underscores the greater immunogenicity of conventional bovine insulin in relation to its highly purified counterpart. However, HPB insulin is still significantly more immunogenic than human insulin of equivalent purity and formulation since the change to human insulin produced a further fall in insulin antibody levels in both Starter and Switch groups. This is in keeping with a previous study 
in which there was a significant fall in antibody level on transfer from highly purified beef to human ultralente insulin [13]. The three aminoacid residues by which beef differs from human insulin (A8, A10 and B30) are relatively close together on the surface of the bovine insulin molecule [14] and create sufficient alteration to induce an immune response greater than that seen with human insulin. As shown previously [6], antibodies induced by bovine insulin cross react to a large extent with the human molecule and in this study levels of antibody binding to bovine and human insulin were reduced to a similar degree after transfer to the human preparation (Table 2).

The relevance of insulin antibodies to the course of diabetes and its complications is disputed [15]. However, injection site lipoatrophy is thought to have an immunological basis and is common during treatment with conventional bovine insulin [16] but has been reported infrequently in patients receiving purified bovine [17] and highly purified porcine insulin [18]. It is therefore of interest that only three patients $(9 \%)$ initially treated with highly purified bovine insulin developed lipoatrophy compared to seven $(22 \%)$ after 6 months on conventional bovine isophane insulin. The condition improved in four of the latter during treatment with HPB and resolved in all within two months of starting human insulin. All patients with lipoatrophy had high levels of insulin antibody which fell on human insulin pari passu with resolution of the lipoatrophy.

Acknowledgements. We thank Anne Banks for technical assistance and Jane Richards and Barbara Sharpe for typing the manuscript. We are grateful to Novo Laboratories for the generous gift of insulins and for financial support to RMW.

\section{References}

1. Reeves WG (1980) Immunology of diabetes and insulin therapy. In: Thompson RA (ed) Recent advances in clinical immunology. Churchill Livingstone, Edinburgh, pp 183-220

2. Walford S, Allison SP, Reeves WG (1982) The effect of insulin antibodies on insulin dose and diabetic control. Diabetologia 22: $106-110$

3. Kurtz AB, Mathews JA, Mustaffa BE, Daggett PR, Nabarro JDN (1980) Decrease of antibodies to insulin, proinsulin and contaminating hormones after changing treatment from conventional beef to purified pork insulin. Diabetologia 18: 147-150
4. Reeves WG (1981) Antibody production during insulin therapy patterns of response and clinical sequels. In: Keck $\mathrm{K}$ and Erb $\mathrm{P}$ (eds) Basic and clinical Aspects of immunity to insulin. Walter De Gruyter, Berlin, pp 219-235

5. Reeves WG, Douglas CA (1982) C-peptide antibodies induced by bovine insulin therapy. Clin Exp Immunol 50: 171-177

6. Reeves WG, Kelly U (1982) Insulin antibodies induced by bovine insulin therapy. Clin Exp Immunol 50: 163-170

7. Peacock I, Taylor A, Tattersall RB, Douglas CA, Reeves WG (1983) Effects of new insulins of insulin and C-peptide antibodies, insulin dose and diabetic control. Lancet 1:149-152

8. Wilson RM, van der Minne P, Deverill I, Heller SR, Gelsthorpe K, Reeves WG, Tattersall RB (1985) Insulin dependence: problems with the classification of 100 consecutive patients. Diabetic Med 2: $167-172$

9. Reeves WG, Barr D, Douglas CA, Gelsthorpe K, Hanning I, Skene A, Wells L, Wilson RM, Tattersall RB (1984) Factors governing the human immune response to injected insulin. Diabetologia 26: 266-271

10. Menard L, Dempsey ME, Blankstein LA, Aleyassine H, Wacks M, Soeldner JS (1980) Quantitative determination of glycosylated haemoglobin AI by agar gel electrophoresis. Clin Chem 26: 1598-1602

11. Peacock I (1984) Glycosylated haemoglobin: measurement and clinical use. J Clin Pathol 37: 841-851

12. Heding LG, Larsson Y, Ludvigsson J (1980) The immunogenicity of insulin preparations. Antibody levels before and after transfer to highly purified porcine insulin. Diabetologia $19: 511-515$

13. Holman RR, Steemson J, Darling P, Reeves WG, Turner RC (1984) Human ultralente insulin. Br Med J 228: 665-669

14. Blundell TL, Cutfield JF, Cutfield SM, Dodson EJ, Dodson GG, Hodgkin DC, Mercola DA (1972) Three-dimensional atomic structure of insulin and its relationship to activity. Diabetes 21: (Suppl 2) 492-505

15. Reeves WG (1985) Immunological aspects of therapy. In: KGMM Alberti \& LP Krall (eds) The Diabetes Annual. Elsevier, Amsterdam, pp 67-81

16. Reeves WG, Allen BR, Tattersall RB (1980) Insulin-induced lipoatrophy: evidence for an immune pathogenesis. Br Med J 280: 1500-1503

17. Evans-Jones LG (1982) Lipoatrophy in a patient on highly purified beef insulin. Arch Dis Child 57: 638-639

18. Jones GR, Statham B, Owens DR, Jones MK, Hayes TM (1981) Lipoatrophy and monocomponent porcine insulin. Br Med J 282: 190

Received: 13 February 1985

and in revised form: 11 June 1985

Dr. W.G. Reeves

Department of Immunology

University Hospital

Nottingham NG7 2UH

UK 